\title{
Beyond cellular detoxification: a plethora of physiological roles for MDR transporter homologs in plants
}

\author{
Estelle Remy and Paula Duque* \\ Instituto Gulbenkian de Ciência, Oeiras, Portugal
}

\section{Edited by:}

Isabel Sá-Correia, Instituto Superior Técnico, Portugal

Reviewed by:

Michael White, Drexel University College of Medicine, USA

Kamil Ruzicka, CEITEC Masaryk

University, Czech Republic

*Correspondence:

Paula Duque, Instituto Gulbenkian de Ciência, Rua da Quinta Grande 6, 2780-156 Oeiras, Portugal

e-mail:duquep@igc.gulbenkian.pt
Higher plants possess a multitude of Multiple Drug Resistance (MDR) transporter homologs that group into three distinct and ubiquitous families-the ATP-Binding Cassette (ABC) superfamily, the Major Facilitator Superfamily (MFS), and the Multidrug And Toxic compound Extrusion (MATE) family. As in other organisms, such as fungi, mammals, and bacteria, MDR transporters make a primary contribution to cellular detoxification processes in plants, mainly through the extrusion of toxic compounds from the cell or their sequestration in the central vacuole. This review aims at summarizing the currently available information on the in vivo roles of MDR transporters in plant systems. Taken together, these data clearly indicate that the biological functions of ABC, MFS, and MATE carriers are not restricted to xenobiotic and metal detoxification. Importantly, the activity of plant MDR transporters also mediates biotic stress resistance and is instrumental in numerous physiological processes essential for optimal plant growth and development, including the regulation of ion homeostasis and polar transport of the phytohormone auxin.

Keywords: ATP-Binding Cassette (ABC), ion homeostasis, Major Facilitator Superfamily (MFS), membrane transporter, Multidrug And Toxin compound Extrusion (MATE), plant systems, polar auxin transport (PAT), xenobiotic detoxification

\section{INTRODUCTION}

Multiple Drug Resistance (MDR), the simultaneous acquisition of resistance to multiple structurally and functionally unrelated cytotoxic compounds, is a widespread biological phenomenon. One way by which a living cell can achieve MDR is by actively extruding toxic compounds. Of the five transporter families hitherto described to include multidrug efflux pumpsSmall Multidrug Resistance (SMR), Resistance/Nodulation/ Division (RND), ATP-Binding Cassette (ABC), Major Facilitator Superfamily (MFS), and Multidrug And Toxic compound Extrusion (MATE) (Paulsen, 2003)—only the ubiquitous ABC, MFS, and MATE are found in higher eukaryotes. As with many other conserved gene families, those of the ABC, MFS, and MATE appear significantly more expanded in plants than in bacteria, yeast or animals, with the Arabidopsis thaliana genome encoding around $130 \mathrm{ABC}, 120 \mathrm{MFS}$, and 58 MATE transporters (Huala et al., 2001; Ren et al., 2004). Strikingly, the majority of the plant transporters belonging to these three families remain to be functionally characterized. We review here the available functional data on these plant transporters (summarized in Table 1), substantiating not only a role in cellular detoxification but also in a wide range of physiological processes.

\section{ABC TRANSPORTERS}

$\mathrm{ABC}$ transporters hydrolyze ATP to transport substrate molecules across cellular membranes. All membrane-bound $\mathrm{ABC}$ proteins consist of a double set of two basic structural modules: a transmembrane domain (TMD), typically containing six membrane-spanning segments, and a cytoplasmic nucleotidebinding domain (NBD), containing the ABC. The so-called full-size $\mathrm{ABC}$ transporters contain all four elements in a single polypeptide chain, while half-size transporters combine two TMD-NBD units as homo- or heterodimers (Higgins et al., 1986). In plants, full-size $\mathrm{ABC}$ transporters have been better studied. Of the 53 Arabidopsis full-size members, all but two can be divided into three groups: the multidrug resistance (MDR) or P-glycoproteins (PGP) belonging to the ABCB subfamily, the multidrug resistance-associated protein (MRP)/ABCC subfamily, and the pleiotropic drug resistance (PDR) of the ABCG subfamily (Sanchez-Fernandez et al., 2001).

$\mathrm{ABC}$ transporters came into spotlight when the MDR1 PGP was found to determine MDR of cancer cells (Chen et al., 1986), and in fact early studies of plant ABCs focused on a potential role in cell detoxification. The sole MDR-like transport mechanism reported in plants so far arose from the functional characterization of one of the 21 full-size members of the $\mathrm{ABCB}$ family, the Arabidopsis $A t A B C B 1$ gene, whose cloning disclosed the occurrence of ABCs in plants (Dudler and Hertig, 1992). Indeed, ectopic expression of $A t A B C B 1$ in Arabidopsis conferred enhanced resistance to multiple xenobiotics, namely to various classes of herbicides including dicamba, pendimethalin, oryzalin, or monosodium acid methanearsonate, pointing to a resistance mechanism relying on decreased retention or increased active xenobiotic efflux from cells (Thomas et al., 2000; Windsor et al., 2003). Several detailed studies also demonstrated that AtABCB1 and the closely related AtABCB19 are required for polar transport of auxin, the major growth phytohormone, by facilitating cellular efflux of indole-3-acetic acid (IAA), its predominant endogenous form (Noh et al., 2001, 2003; Lin and Wang, 2005; Lewis et al., 2007). Another extensively studied ABCB transporter, AtABCB4, was implicated in root shootward auxin transport and appears to function in both cellular IAA efflux and influx (Santelia et al., 
Table 1 | Representative examples of plant MDR transporter homologs and their physiological functions.

\begin{tabular}{|c|c|c|c|}
\hline Transporter & Species & Biological function(s) & References \\
\hline \multicolumn{4}{|c|}{ MDR/PGP-FULL-SIZE MEMBERS OF THE ABCB SUBFAMILY OF ABC TRANSPORTERS } \\
\hline ABCB1/PGP1 & Arabidopsis thaliana & $\begin{array}{l}\text { Resistance to multiple xenobiotics including herbicides } \\
\text { Polar auxin transport }\end{array}$ & $\begin{array}{l}\text { Thomas et al., 2000; Noh et al., 2001, 2003; } \\
\text { Windsor et al., 2003; Lin and Wang, 2005; } \\
\text { Lewis et al., } 2007\end{array}$ \\
\hline ABCB4/PGP4 & Arabidopsis thaliana & Polar auxin transport & $\begin{array}{l}\text { Santelia et al., 2005; Terasaka et al., 2005; Cho } \\
\text { et al., 2007; Lewis et al., 2007; Wu et al., } \\
\text { 2007; Yang and Murphy, } 2009\end{array}$ \\
\hline ABCB14/PGP14 & Arabidopsis thaliana & Polar auxin transport Stomatal closure regulation & Lee et al., 2008; Kaneda et al., 2011 \\
\hline ABCB15/PGP15 & Arabidopsis thaliana & Polar auxin transport & Kaneda et al., 2011 \\
\hline ABCB19/PGP19 & Arabidopsis thaliana & Polar auxin transport & $\begin{array}{l}\text { Noh et al., 2001, 2003; Lin and Wang, 2005; } \\
\text { Lewis et al., } 2007\end{array}$ \\
\hline ABCB21/PGP21 & Arabidopsis thaliana & Polar auxin transport & Kamimoto et al., 2012 \\
\hline
\end{tabular}

\section{ABCC (MRP) SUBFAMILY OF ABC TRANSPORTERS}

ABCC1/MRP1 Arabidopsis thaliana

ABCC2/MRP2 Arabidopsis thaliana

\section{ABCC3/MRP3 Arabidopsis thaliana}

MRP4/ABCC4 Arabidopsis thaliana

ABCC5/MRP5 Arabidopsis thaliana

MRP3 Zea mays

MRP4 Zea mays

\section{PDR - FULL-SIZE MEMBERS OF THE ABCG SUBFAMILY OF ABC TRANSPORTERS}

ABCG30/PDR2 Arabidopsis thaliana

ABCG36/PDR8 Arabidopsis thaliana

ABCG37/PDR9 Arabidopsis thaliana

ABCG40/PDR12 Arabidopsis thaliana

$\begin{array}{lll}\text { PDR1 } & \text { Nicotiana plumbaginifolia } & \text { Terpene transport Basal defense } \\ \text { PDR5 } & \text { Nicotiana tabacum } & \text { Herbivore defense } \\ \text { TUR2 } & \text { Spirodella polyrhiza } & \text { Terpene transport including sclareol } \\ \text { LR34 } & \text { Triticum spp. } & \text { Resistance to fungal pathogens }\end{array}$

\section{MAJOR FACILITATOR SUPERFAMILY (MFS)}

NRT1.1/CHL1 Arabidopsis thaliana

$\begin{array}{ll}\text { Pht1;1 } & \text { Arabidopsis thaliana } \\ \text { Pht1;4 } & \text { Arabidopsis thaliana } \\ \text { Pht1;5 } & \text { Arabidopsis thaliana } \\ \text { Pht1;8 } & \text { Arabidopsis thaliana } \\ \text { Pht1;9 } & \text { Arabidopsis thaliana } \\ \text { Pht4;1 } & \text { Arabidopsis thaliana }\end{array}$

Sclareol resistance ABA transport Lead detoxification

Nitrate sensing Regulation of nascent organ development, stomatal opening, seed germination and root architecture

Root exudation of phytochemicals

Resistance to cadmium and sodium Resistance to fungal transport Root exudation of phytochemicals

Resistance to synthetic auxins IBA transport

Pi uptake under Pi-sufficient and Pi-deficient environmenta conditions

Pi uptake under Pi-sufficient and Pi-deficient environmental Misson et al., 2004; Shin et al., 2004 conditions

Pi mobilization from phosphorous source to sink organs

Pi uptake under phosphate starvation

Pi uptake under phosphate starvation

Basal defense against pathogens
Lu et al., 1997; Raichaudhuri et al., 2009; Song et al., 2010; Park et al., 2012; Burla et al., 2013

Lu et al., 1998; Song et al., 2010; Park et al., 2012; Burla et al., 2013

Tommasini et al., 1998

Klein et al., 2004

Gaedeke et al., 2001; Klein et al., 2003; Suh et al., 2007; Nagy et al., 2009; Kang et al., 2011 Goodman et al., 2004

Shi et al., 2007

\section{Badri et al., 2009}

Kobae et al., 2006; Stein et al., 2006; Kim A et al., 2007, 2010; Strader and Bartel, 2009; Badri et al., 2012; Underwood and Somerville, 2013; Xin et al., 2013

Ito and Gray, 2006; Ruzicka et al., 2010; Badri et al., 2012

Campbell et al., 2003; Lee et al., 2005; Kang et al., 2010

Jasinski et al., 2001; Stukkens et al., 2005

Bienert et al., 2012

van den Brule et al., 2002

Krattinger et al., 2009; Risk et al., 2013

Guo et al., 2001, 2003; Alboresi et al., 2005;

Remans et al., 2006; Walch-Liu and Forde, 2008; Ho et al., 2009

Shin et al., 2004

Nagarajan et al., 2011

Remy et al., 2012

Remy et al., 2012

Wang et al., 2011 
Table 1 | Continued

\begin{tabular}{|c|c|c|c|}
\hline Transporter & Species & Biological function(s) & References \\
\hline Pht4;2 & Arabidopsis thaliana & Root starch accumulation Leaf size & Irigoyen et al., 2011 \\
\hline Pht $4 ; 6$ & Arabidopsis thaliana & Tolerance to salt stress Biotic stress resistance & Cubero et al., 2009; Hassler et al., 2012 \\
\hline STP1 & Arabidopsis thaliana & $\begin{array}{l}\text { Uptake of hexoses by seeds and seedlings Monosaccharide } \\
\text { import into guard cells }\end{array}$ & Sherson et al., 2000 \\
\hline ZIF1 & Arabidopsis thaliana & $\begin{array}{l}\text { Zinc tolerance via vacuolar sequestration of nicotianamine } \\
\text { Iron homeostasis }\end{array}$ & Haydon and Cobbett, 2007; Haydon et al., 2012 \\
\hline ZIF2 & Arabidopsis thaliana & Zinc tolerance via vacuolar sequestration & Remy et al., 2014 \\
\hline ZIFL1 & Arabidopsis thaliana & $\begin{array}{l}\text { Resistance to 2,4-D Cesium sensitivity Modulation of polar } \\
\text { auxin transport Regulation of stomatal apertures and } \\
\text { drought stress tolerance }\end{array}$ & Remy et al., 2013a,b \\
\hline \multicolumn{4}{|c|}{ MATE FAMILY } \\
\hline ADP1 & Arabidopsis thaliana & Regulation of local auxin biosynthesis and plant architecture & Li et al., 2014 \\
\hline ADS1 & Arabidopsis thaliana & Negative regulator of plant biotic stress resistance & Sun et al., 2011 \\
\hline ALF5 & Arabidopsis thaliana & Root protection from inhibitory compounds & Diener et al., 2001 \\
\hline DTX15/FFT & Arabidopsis thaliana & $\begin{array}{l}\text { Flavonoid transport Root growth, seed development and } \\
\text { germination, and pollen development }\end{array}$ & Thompson et al., 2010 \\
\hline EDS5 & Arabidopsis thaliana & SA-dependent signaling for plant disease resistance & $\begin{array}{l}\text { Nawrath et al., 2002; Serrano et al., 2013; } \\
\text { Yamasaki et al., } 2013\end{array}$ \\
\hline FRD3 & Arabidopsis thaliana & $\begin{array}{l}\text { Citrate-mediated iron shoot/root translocation Zinc } \\
\text { tolerance }\end{array}$ & Durrett et al., 2007; Pineau et al., 2012 \\
\hline MATE & Arabidopsis thaliana & Citrate-mediated aluminum tolerance & Liu et al., 2009 \\
\hline TT12 & Arabidopsis thaliana & $\begin{array}{l}\text { Vacuolar transport of proanthocyanidin precursors in } \\
\text { seed-coat cells }\end{array}$ & Debeaujon et al., 2001; Marinova et al., 2007 \\
\hline ZRZ & Arabidopsis thaliana & Organ initiation & Burko et al., 2011 \\
\hline MATE1 & $\begin{array}{l}\text { Eucalyptus } \\
\text { camaldulensis }\end{array}$ & Citrate-mediated aluminum tolerance & Sawaki et al., 2013 \\
\hline AACT1 & Hordeum vulgare & Citrate-mediated aluminum tolerance & Furukawa et al., 2007; Zhou et al., 2013 \\
\hline MATE1 & Lotus japonicum & Citrate-mediated iron translocation to nodule tissues & Takanashi et al., 2013 \\
\hline MATE1 & Medicago truncatula & Vacuolar transport of proanthocyanidin precursors & Zhao and Dixon, 2009 \\
\hline MATE2 & Medicago truncatula & Vacuolar transport of anthocyanins & Zhao et al., 2011 \\
\hline JAT1 & Nicotiana tabacum & Vacuolar sequestration of nicotine & Morita et al., 2009 \\
\hline MATE1 & Nicotiana tabacum & Vacuolar sequestration of nicotine & Shoji et al., 2009 \\
\hline MATE2 & Nicotiana tabacum & Vacuolar sequestration of nicotine & Shoji et al., 2009 \\
\hline FRDL4 & Oryza satviva & Citrate-mediated aluminum tolerance & Yokosho et al., 2011 \\
\hline FRDL1 & Oryza satviva & Citrate-mediated iron shoot/root translocation & Yokosho et al., 2009 \\
\hline MATE1 & Oryza satviva & $\begin{array}{l}\text { Negative regulator of biotic stress and arsenic resistance } \\
\text { Plant development }\end{array}$ & Tiwari et al., 2014 \\
\hline MATE2 & Oryza satviva & $\begin{array}{l}\text { Negative regulator of biotic stress and arsenic resistance } \\
\text { Plant development }\end{array}$ & Tiwari et al., 2014 \\
\hline Alt(SB) & Sorghum bicolor & Citrate-mediated aluminum tolerance & Magalhaes et al., 2007 \\
\hline MATE & Vigna umbellata & Citrate-mediated aluminum tolerance & Yang et al., 2011 \\
\hline
\end{tabular}

2005; Terasaka et al., 2005; Cho et al., 2007; Lewis et al., 2007; Wu et al., 2007; Yang and Murphy, 2009). Interestingly, recent findings indicate that AtABCB4 is also able to mediate cellular influx of 2,4-dichlorophenoxyacetic acid (2,4-D), rendering the carrier a target of the herbicidal activity of this synthetic auxin (Kubes et al., 2012). An Arabidopsis AtABCB4 homolog, AtABCB21, has also been described to mediate IAA import/export, depending on the cytoplasmic concentration of the phytohormone (Kamimoto et al., 2012), while AtABCB14 and AtABCB15 have been associated with polar auxin transport (PAT) in inflorescence stems (Kaneda et al., 2011). Thus, all plant full-size ABCB (MRP/PGP) transporters characterized to date contribute to PAT in vegetative tissues, directing long-distance auxin transport in mature plants. Nevertheless, AtABCB14 was first reported as a malate importer regulating stomatal closure (Lee et al., 2008), suggesting that full-size $\mathrm{ABCB}$ carriers may play important roles in other key processes.

ABCC (MRP) transporters, which have been typically associated with detoxification processes, were first identified in human drug-resistant cancer cells (Cole et al., 1992). Most of the 15 Arabidopsis members are localized at the vacuolar membrane (Rea, 2007), representing the only tonoplastic full-size ABC 
transporters described to date (Kang et al., 2011). A common cellular detoxification strategy in plants is to sequester toxic compounds in the vacuole to avoid deleterious effects on cytosolic metabolism. Early studies showed that plant vacuolar accumulation of glutathionated xenobiotics is ATP-dependent (Martinoia et al., 1993), prompting the identification of the first plant ABCC transporters. Indeed, AtABCC1, AtABCC2, and AtABCC3 are implicated in vacuolar sequestration of conjugated xenobiotics such as herbicides, with the latter two transporters functioning also in endogenous chlorophyll catabolite detoxification (Lu et al., 1997, 1998; Tommasini et al., 1998). Importantly, AtABCC1 and AtABCC2 were recently described as phytochelatin transporters with overlapping functions in plant tolerance to the metalloid arsenic and the heavy metals cadmium and mercury (Song et al., 2010; Park et al., 2012). There is also evidence pointing to a role of AtABCC3 and AtABCC6 in responses to cadmium stress (Tommasini et al., 1998; Gaillard et al., 2008). Furthermore, both AtABCC1 (Raichaudhuri et al., 2009) and AtABCC4 (Klein et al., 2004) are involved in vacuolar sequestration of excess folates, whereas AtABCC5 is a high-affinity inositol hexakisphosphate $\left(\mathrm{InsP}_{6}\right)$ transporter modulating seed phytate content (Nagy et al., 2009) as its maize homolog ZmMRP4 (Shi et al., 2007). Interestingly, both AtABCC4 (Klein et al., 2004) and AtABCC5 (Gaedeke et al., 2001; Klein et al., 2003; Suh et al., 2007) regulate stomatal movements, which in the case of AtABCC5 could be linked to its InsP $_{6}$ transport activity (Kang et al., 2011). Finally, ZmMRP3 was shown to affect vacuolar anthocyanin accumulation (Goodman et al., 2004), and a recent study implicated AtABCC1 and AtABCC2 in vacuolar sequestration of a conjugate of the phytohormone abscisic acid (ABA) (Burla et al., 2013). It is therefore clear that plant $\mathrm{ABCC}$ transporters are involved in a range of processes beyond detoxification, such as the transport of primary and storage compounds or hormones and the control of stomatal apertures.

PDR proteins are specific to plants and fungi and in Arabidopsis comprise the 15 full-size members of the ABCG subfamily, which uniquely among $\mathrm{ABC}$ feature a reverse organization of the NBD and TMD domains in each unit (Crouzet et al., 2006). All PDRs characterized so far are plasma membrane transporters (Kang et al., 2011), and the first to be identified in plants, the Spirodella polyrhiza SpTUR2 and the Nicotiana plumbaginifolia NpPDR1, mediate the transport of terpenes (Jasinski et al., 2001; van den Brule et al., 2002). SpTUR2 expression in Arabidopsis confers resistance to the diterpenoid sclareol, as does the Arabidopsis AtABCG40 (Campbell et al., 2003) later shown to function in cellular uptake of the sesquiterpenoid ABA (Kang et al., 2010). Intriguingly, AtABCG40 also mediates detoxification of the heavy metal lead via a glutathione-independent process (Lee et al., 2005). Another PDR transporter, AtABCG36, is involved in cadmium (Kim et al., 2007) and sodium toxicity (Kim et al., 2010) resistance. Following the findings that NpPDR1 secretes antifungal terpenoids (Jasinski et al., 2001) and contributes to basal plant defense (Stukkens et al., 2005), AtABCG36 was identified as a key factor in the resistance to fungal and bacterial pathogens (Kobae et al., 2006; Stein et al., 2006; Underwood and Somerville, 2013; Xin et al., 2013). Moreover, both AtABCG36 and AtABCG37 excrete a range of synthetic auxins, including 2,4-D, and indole-3-butyric acid (IBA), the natural IAA precursor (Ito and Gray, 2006; Strader and Bartel, 2009; Ruzicka et al., 2010). Interestingly, AtABCG36, AtABCG37, and AtABCG30 are involved in root exudation of phytochemicals (Badri et al., 2009, 2012). Recent studies implicate the tobacco NtPDR5 in herbivore defense (Bienert et al., 2012), while the wheat PDR carrier LR34 confers resistance to fungal pathogens (Krattinger et al., 2009; Risk et al., 2013). Thus, plant full-size ABCG proteins play a preponderant role in metal and xenobiotic detoxification as well as in biotic stress resistance, but also fulfill functions in phytohormone transport.

\section{MFS TRANSPORTERS}

After ABCs, the MFS represents the second largest group of transporters on earth. All MFS proteins are single-polypeptide secondary carriers capable of transporting only small molecules across membranes via a uniport, symport, or antiport mechanism using chemiosmotic gradients as energy source (Pao et al., 1998). Their protein domain organization typically consists of two TMDs, each composed of six membrane-spanning segments, flanking a central hydrophilic pore (Goswitz and Brooker, 1995).

The few plant MFS members characterized to date have been essentially implicated in sugar (Buttner, 2007), or nitrate and oligopeptide (Tsay et al., 2007) transport. The first monosaccharide transporter identified in higher plants was the Arabidopsis STP1 (Sauer et al., 1990), which is able to transport a wide range of hexoses via a proton symport mechanism (Boorer et al., 1994) and has reported functions in sugar uptake by seeds and seedlings (Sherson et al., 2000) as well as by guard cells (Stadler et al., 2003). A few other Arabidopsis MFS sugar transporters have been functionally characterized, such as PLT5, a broad-spectrum $\mathrm{H}^{+}$symporter for polyols as well as for different hexoses and pentoses in sink tissues (Klepek et al., 2005; Reinders et al., 2005). As for plant MFS nitrate transporters, by far the best characterized is AtNRT1.1 (CHL1) that functions as a nitrate sensor (Ho et al., 2009). NRT1.1 possesses dual-affinity nitrate uptake activity (Liu et al., 1999) and has been assigned a variety of signaling functions, including in the modulation of nascent organ development (Guo et al., 2001), stomatal opening (Guo et al., 2003), seed germination (Alboresi et al., 2005), and root architecture (Remans et al., 2006; Walch-Liu and Forde, 2008). Importantly, this carrier also represses lateral root growth at low nitrate availability by promoting shootward auxin transport out of these roots, thus connecting nutrient sensing and auxin-dependent developmental adaptation (Krouk et al., 2010).

Furthermore, plant MFS transporters belonging to the Pht1 and Pht 4 families mediate high- and low-affinity inorganic phosphate (Pi) transport, respectively (Guo et al., 2008; Nussaume et al., 2011). Of the nine Arabidopsis Pht1 transporters, those characterized so far are plasma-membrane-localized, with Pht $1 ; 1$, Pht1;4, Pht1;8, and Pht1;9 ensuring environmental Pi acquisition (Misson et al., 2004; Shin et al., 2004; Remy et al., 2012), while Pht 1;5 mobilizes Pi from phosphorous source to sink organs (Nagarajan et al., 2011). On the other hand, the six Arabidopsis Pht 4 members are suggested to mediate Pi transfer across internal cellular membranes (Guo et al., 2008), with the plastidic Pht4;1 and Pht4;2 influencing basal defense against pathogens (Wang 
et al., 2011) and starch accumulation and leaf size (Irigoyen et al., 2011), respectively. Finally, the Golgi-localized Pht4;6 determines salt tolerance and biotic stress resistance, affecting also plant growth and development (Cubero et al., 2009; Hassler et al., 2012).

A role for the MFS in plant metal homeostasis is also beginning to emerge. The Arabidopsis tonoplast-localized ZIF1, initially described as a transporter involved in basal tolerance to the heavy metal zinc (Haydon and Cobbett, 2007), was later additionally implicated in iron homeostasis and its substrate identified as the low molecular mass metal chelator, nicotianamine (Haydon et al., 2012). Very recently, the ZIF2 carrier was reported to also sustain zinc tolerance in Arabidopsis by mediating its root vacuolar sequestration. Interestingly, high zinc favors an intron retention event in the ZIF2 5'UTR, promoting translation of the mRNA to enhance plant tolerance to the metal (Remy et al., 2014). By contrast, a close Arabidopsis ZIF1 homolog, ZIFL1, does not function in zinc homeostasis but instead confers resistance to 2,4-D and sensitivity to the heavy metal cesium. This transporter exhibits $\mathrm{H}^{+}$-coupled $\mathrm{K}^{+}$transport activity and fulfills two distinct biological functions-while the full-length ZIFL1 protein is a root tonoplastic transporter modulating shootward auxin transport, a truncated splice form is targeted to the plasma membrane of guard cells and regulates drought stress tolerance (Remy et al., 2013b). The functional characterization of the ZIF2 and ZIFL1 transporters has hence revealed striking examples of the biological impact of alternative splicing in plants, which remains largely unknown (Carvalho et al., 2013).

\section{MATE TRANSPORTERS}

MATE transporters comprise the most recently identified of multidrug transporter families (Brown et al., 1999). They are characterized by the presence of 12 putative transmembrane segments and like MFSs are secondary active carriers that depend on electrochemical gradients for their activity. Plant MATEs are thought to function as $\mathrm{H}^{+}$-coupled antiporters and reportedly localize at the plasma membrane or the tonoplast, carrying a diverse range of compounds.

Transport activity for plant MATEs was first demonstrated for the Arabidopsis DTX1 and ALF5. When heterologously expressed in Escherichia coli, AtDTX1 serves as an efflux carrier for the antibiotic norfloxacin, ethidium bromide, the plant-derived alkaloids berberine, and palmatine as well as cadmium (Li et al., 2002). Genetic analysis of AtALF5, whose expression in yeast confers resistance to tetramethylammonium, revealed a role in root protection from inhibitory compounds (Diener et al., 2001). However, the first plant MATE transporter to be identified, AtTT12, was implicated in the vacuolar accumulation of flavonoids, a class of plant-specific secondary metabolites, in the seed coat (Debeaujon et al., 2001), and later confirmed to be a tonoplast-localized vacuolar flavonoid $/ \mathrm{H}^{+}$-antiporter active in proanthocyanidin-accumulating seed-coat cells (Marinova et al., 2007). Several other studies have corroborated a role for MATEs in the vacuolar accumulation of proanthocyanins and anthocyanins in different plant tissues, including in Arabidopsis, Medicago truncatula, tomato, and grapevine (Mathews et al., 2003; Gomez et al., 2009; Zhao and Dixon, 2009; Thompson et al.,
2010; Zhao et al., 2011). MATEs have also been shown to mediate vacuolar transport of the major alkaloid nicotine in tobacco cells (Morita et al., 2009; Shoji et al., 2009).

Importantly, vital roles for MATE transporters in plant tolerance to the heavy metal aluminum (Al) have been established. Plants cope with $\mathrm{Al}$ phytotoxic concentrations in the rhizosphere by releasing organic anions such as citrate that form stable nontoxic complexes with the metal (Magalhaes, 2010), and MATEs have been identified as major determinants of this Al tolerance strategy in sorghum (Magalhaes et al., 2007), barley (Furukawa et al., 2007), and rice (Yokosho et al., 2011). Citrate transporters of the MATE family have also been linked to Al tolerance in Arabidopsis, maize, wheat, rye, rice bean, or Eucalyptus camaldulensis, with a few of these MATEs conferring $\mathrm{Al}$ resistance when heterologously expressed in other plant species (Liu et al., 2009; Ryan et al., 2009; Maron et al., 2010; Yokosho et al., 2010; Yang et al., 2011; Sawaki et al., 2013; Zhou et al., 2013). Interestingly, citrate transport by AtFRD3 and OsFRDL1 is required for iron root/shoot translocation in Arabidopsis (Durrett et al., 2007) and rice (Yokosho et al., 2009), respectively. More recently, AtFDR3 was implicated in plant zinc homeostasis (Pineau et al., 2012), while a citrate MATE transporter from the model legume Lotus japonica assists in iron translocation to nodule tissues (Takanashi et al., 2013).

Plant MATEs also function in the response to pathogen infection. An early study revealed a role for AtEDS5 in salicylic acid (SA)-dependent disease resistance signaling (Nawrath et al., 2002). Subsequent findings that the transporter mediates SA export from the chloroplast, where synthesis of the signaling molecule occurs, provided mechanist insight into EDS5's control of plant disease tolerance (Serrano et al., 2013; Yamasaki et al., 2013). Another Arabidopsis MATE involved in SA-mediated pathogen response is ADS1, a negative regulator of plant biotic stress resistance (Sun et al., 2011). More recently, heterologous expression of two rice MATE genes in Arabidopsis was reported to affect not only pathogen susceptibility, but also arsenic sensitivity and plant development (Tiwari et al., 2014). Functional characterization of another two plant MATE transporters, AtZRZ and AtADP1, substantiated a role in development, namely in plant architecture and organ initiation (Burko et al., 2011; Li et al., 2014).

\section{CONCLUDING REMARKS}

Plant MDR transporter homologs substantially contribute to cellular detoxification of metals and xenobiotic compounds as well as to biotic stress resistance. Besides these rather expected functions, most of the available functional data show that these transporters also fulfill essential roles in numerous physiological processes, ranging from hormone transport to the regulation of ion homeostasis and stomatal movements, thus modulating plant growth and development. Hitherto, and to the best of our knowledge, an MDR transporter sensu stricto, i.e., a membrane pump that exclusively catalyzes the cellular efflux of a broad range of chemically distinct xenobiotics, has not been identified in plants.

Besides global ion homeostasis regulation, in which all three plant MDR transporter families have long been implicated, the physiological process reported to date to require the activity of the 
largest number of MDR transporter homologs is PAT, as exemplified in Figure 1 for root shootward auxin transport in Arabidopsis. Many key aspects of plant development are regulated by PAT, whose rate-limiting step, cellular IAA efflux, relies primarily on the regulated polar localization of PIN transporters at the plasma membrane (Petrasek et al., 2006; Wisniewska et al., 2006). Furthermore, all six characterized members of the Arabidopsis PGP/ABCB subfamily contribute to PAT. While PINs and ABCBs

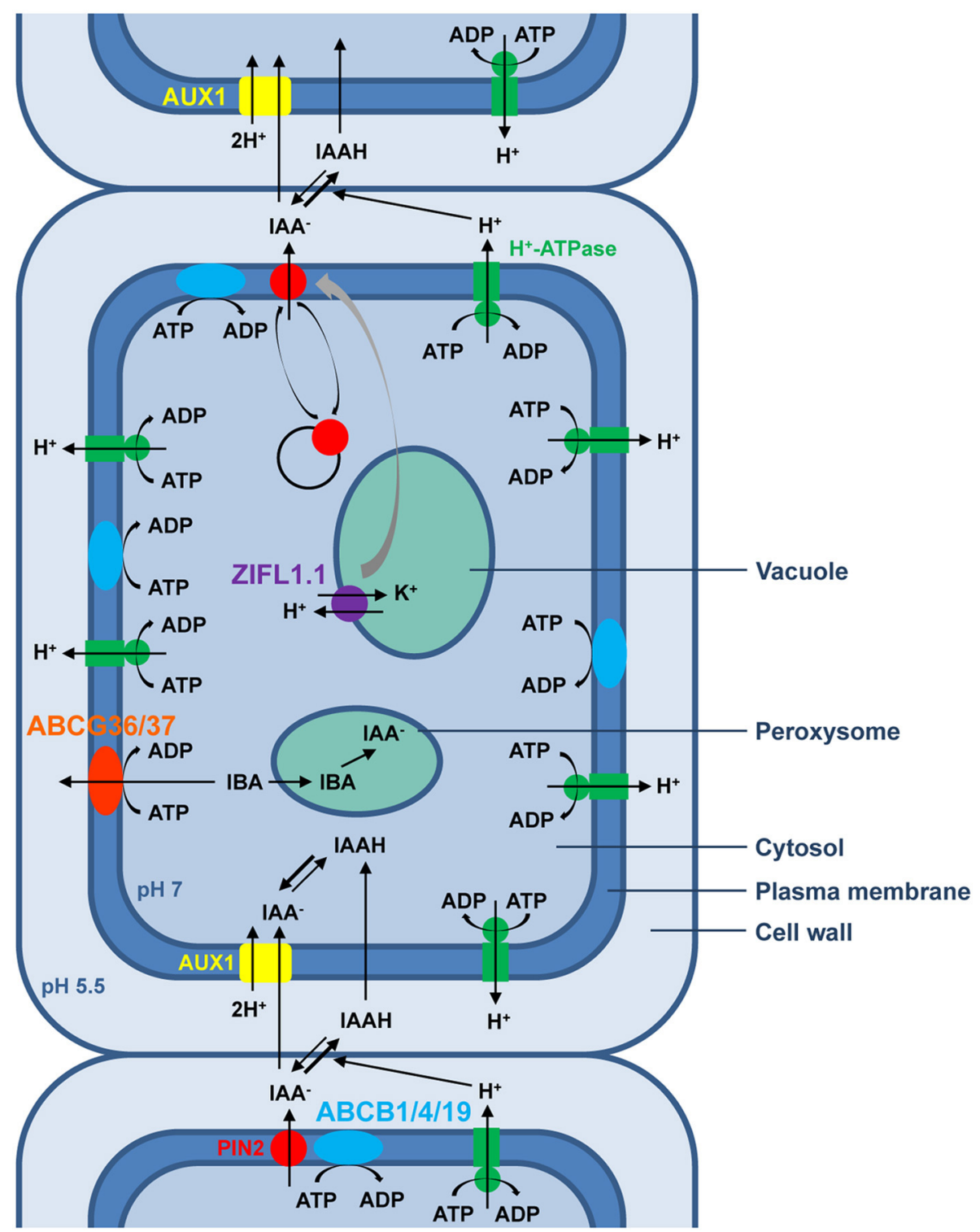

FIGURE 1 | Schematic representation of polar auxin transport (PAT) in epidermal cells of the Arabidopsis root tip. According to the chemiosmotic hypothesis, the proton gradient generated primarily by plasma membrane $\mathrm{H}^{+}$-ATPases between the neutral cytoplasm and the acidic extracellular space drives the polarized auxin cell-to-cell movement. In the acidic apoplastic environment, a fraction of the weak acid IAA exists in its undissociated form, which can passively diffuse through the plasma membrane inside the cell. By contrast, the non-lipophilic and therefore less permeable proton-dissociated auxin fraction requires the amino acid permease-like AUX1, which catalyzes proton symport activity, to enter the cell. In the neutral cytosolic environment, IAA exists mainly in its membrane-impermeant anionic form that requires active transport to exit the cell. Hitherto, two distinct protein families whose members possess IAA-exporting activity have been associated with cellular polar auxin efflux. The best characterized auxin efflux carriers are members of the unique and plant-specific PIN protein family, believed to be secondary transporters energized by proton gradients. By contrast, some plant homologs of the human MDR/PGP transporters belonging to the $A B C B$ subfamily, such as $A B C B 1, A B C B 4$, and $A B C B 19$, have been implicated in ATP-energized auxin efflux. Although activity of $A B C B$ s and the asymmetrical localization of $A U X 1$ facilitates directionality of auxin transport, the bias, and rate of shootward auxin transport are mainly attributable to the highly regulated polar localization of the PIN2 transporter. Dynamic polar sorting of PIN2 at the plasma membrane is sustained by repeated steps of endocytic internalization and recycling back to the plasma membrane via exocytosis. In addition, potassium transport activity of the ZIFL1.1 tonoplastic carrier exerts a protective effect on PIN2

plasma-membrane stability. The hormonal activity of the auxin precursor IBA requires its conversion to IAA through $\beta$-oxydation in the peroxysome. Two members of the G-family of $A B C$ transporters, $A B C G 36$ and ABCG37, localize to the outward face of root epidermal cells and efflux IBA from root cells. 
define two distinct IAA efflux systems, roles for ABCBs in providing IAA to PINs for vectorial transport (Mravec et al., 2008) or in stabilizating PINs at the plasma membrane to enhance IAA specificity (Blakeslee et al., 2007; Titapiwatanakun et al., 2009) have been demonstrated. Thus, both efflux transport systems act concertedly to generate and maintain auxin gradients. Importantly, auxin distribution can also be influenced by directional IBA transport across the plasma membrane, a role fulfilled by AtABCG36 and AtABCG37 that act redundantly at outermost root plasma membranes to export IBA from cells, thereby contributing to IBA and auxinic compound sensitivity and regulating multiple aspects of primary root development (Ruzicka et al., 2010). Apart from ABC transporters, an Arabidopsis MFS member was recently shown to act as a general positive modulator of PAT by stabilizing PIN plasma-membrane abundance-ZIFL1.1 activity is required for fine-tuning of root shootward auxin transport rates under conditions normally triggering PIN degradation and regulates lateral root growth and root gravitropic responses (Remy et al., 2013a,b). Moreover, the MATE AtADP1 transporter appears to regulate local auxin levels in meristematic tissues to control lateral organ growth in Arabidopsis (Li et al., 2014). Future characterization of additional plant MFS and MATE members will likely unveil a broader role for these transporter families in PAT.

\section{ACKNOWLEDGMENTS}

We apologize to all authors whose highly relevant work was not included due to space constraints. Estelle Remy was supported by Fundação para a Ciência e a Tecnologia (Grant EXPL/ AGR-PRO/1013/2013 and PostDoctoral Fellowship SFRH/BPD/ 44640/2008).

\section{REFERENCES}

Alboresi, A., Gestin, C., Leydecker, M. T., Bedu, M., Meyer, C., and Truong, H. N. (2005). Nitrate, a signal relieving seed dormancy in Arabidopsis. Plant Cell Environ. 28, 500-512. doi: 10.1111/j.1365-3040.2005.01292.x

Badri, D. V., Chaparro, J. M., Manter, D. K., Martinoia, E., and Vivanco, J. M. (2012). Influence of ATP-binding cassette transporters in root exudation of phytoalexins, signals, and in disease resistance. Front Plant Sci. 3:149. doi: 10.3389/fpls.2012.00149

Badri, D. V., Quintana, N., El Kassis, E. G., Kim, H. K., Choi, Y. H., Sugiyama, A., et al. (2009). An ABC transporter mutation alters root exudation of phytochemicals that provoke an overhaul of natural soil microbiota. Plant Physiol. 151, 2006-2017. doi: 10.1104/pp.109.147462

Bienert, M. D., Siegmund, S. E., Drozak, A., Trombik, T., Bultreys, A., Baldwin, I. T., et al. (2012). A pleiotropic drug resistance transporter in Nicotiana tabacum is involved in defense against the herbivore Manduca sexta. Plant J. 72, 745-757. doi: 10.1111/j.1365-313X.2012.05108.x

Blakeslee, J. J., Bandyopadhyay, A., Lee, O. R., Mravec, J., Titapiwatanakun, B., Sauer, M., et al. (2007). Interactions among PIN-FORMED and Pglycoprotein auxin transporters in Arabidopsis. Plant Cell 19, 131-147. doi: 10.1105/tpc.106.040782

Boorer, K. J., Loo, D. D., and Wright, E. M. (1994). Steady-state and presteadystate kinetics of the $\mathrm{H}^{+}$/hexose cotransporter (STP1) from Arabidopsis thaliana expressed in Xenopus oocytes. J. Biol. Chem. 269, 20417-20424.

Brown, M. H., Paulsen, I. T., and Skurray, R. A. (1999). The multidrug efflux protein NorM is a prototype of a new family of transporters. Mol. Microbiol. 31, 394-395. doi: 10.1046/j.1365-2958.1999.01162.x

Burko, Y., Geva, Y., Refael-Cohen, A., Shleizer-Burko, S., Shani, E., Berger, Y., et al. (2011). From organelle to organ: ZRIZI MATE-Type transporter is an organelle transporter that enhances organ initiation. Plant Cell Physiol. 52, 518-527. doi: $10.1093 / \mathrm{pcp} / \mathrm{pcr} 007$
Burla, B., Pfrunder, S., Nagy, R., Francisco, R. M., Lee, Y., and Martinoia, E. (2013). Vacuolar transport of abscisic acid glucosyl ester is mediated by ATP-binding cassette and proton-antiport mechanisms in Arabidopsis. Plant Physiol. 163, 1446-1458. doi: 10.1104/pp.113.222547

Buttner, M. (2007). The monosaccharide transporter(-like) gene family in Arabidopsis. FEBS Lett. 581, 2318-2324. doi: 10.1016/j.febslet.2007.03.016

Campbell, E. J., Schenk, P. M., Kazan, K., Penninckx, I. A., Anderson, J. P., Maclean, D. J., et al. (2003). Pathogen-responsive expression of a putative ATP-binding cassette transporter gene conferring resistance to the diterpenoid sclareol is regulated by multiple defense signaling pathways in Arabidopsis. Plant Physiol. 133, 1272-1284. doi: 10.1104/pp.103.024182

Carvalho, R. F., Feijao, C. V., and Duque, P. (2013). On the physiological significance of alternative splicing events in higher plants. Protoplasma 250, 639-650. doi: 10.1007/s00709-012-0448-9

Chen, C. J., Chin, J. E., Ueda, K., Clark, D. P., Pastan, I., Gottesman, M. M., et al. (1986). Internal duplication and homology with bacterial transport proteins in the mdr1 (P-glycoprotein) gene from multidrug-resistant human cells. Cell 47, 381-389. doi: 10.1016/0092-8674(86)90595-7

Cho, M., Lee, S. H., and Cho, H. T. (2007). P-glycoprotein4 displays auxin efflux transporter-like action in Arabidopsis root hair cells and tobacco cells. Plant Cell 19, 3930-3943. doi: 10.1105/tpc.107.054288

Cole, S. P., Bhardwaj, G., Gerlach, J. H., Mackie, J. E., Grant, C. E., Almquist, K. C., et al. (1992). Overexpression of a transporter gene in a multidrugresistant human lung cancer cell line. Science 258, 1650-1654. doi: 10.1126/science. 1360704

Crouzet, J., Trombik, T., Fraysse, A. S., and Boutry, M. (2006). Organization and function of the plant pleiotropic drug resistance $\mathrm{ABC}$ transporter family. FEBS Lett. 580, 1123-1130. doi: 10.1016/j.febslet.2005.12.043

Cubero, B., Nakagawa, Y., Jiang, X. Y., Miura, K. J., Li, F., Raghothama, K. G., et al. (2009). The phosphate transporter PHT4;6 is a determinant of salt tolerance that is localized to the Golgi apparatus of Arabidopsis. Mol. Plant 2, 535-552. doi: $10.1093 / \mathrm{mp} / \mathrm{ssp} 013$

Debeaujon, I., Peeters, A. J., Leon-Kloosterziel, K. M., and Koornneef, M. (2001). The TRANSPARENT TESTA12 gene of Arabidopsis encodes a multidrug secondary transporter-like protein required for flavonoid sequestration in vacuoles of the seed coat endothelium. Plant Cell 13, 853-871. doi: 10.1105/tpc.13.4.853

Diener, A. C., Gaxiola, R. A., and Fink, G. R. (2001). Arabidopsis ALF5, a multidrug efflux transporter gene family member, confers resistance to toxins. Plant Cell 13, 1625-1638. doi: 10.1105/tpc.13.7.1625

Dudler, R., and Hertig, C. (1992). Structure of an mdr-like gene from Arabidopsis thaliana. Evolutionary implications. J. Biol. Chem. 267, 5882-5888.

Durrett, T. P., Gassmann, W., and Rogers, E. E. (2007). The FRD3-mediated efflux of citrate into the root vasculature is necessary for efficient iron translocation. Plant Physiol. 144, 197-205. doi: 10.1104/pp.107.097162

Furukawa, J., Yamaji, N., Wang, H., Mitani, N., Murata, Y., Sato, K., et al. (2007). An aluminum-activated citrate transporter in barley. Plant Cell Physiol. 48, 1081-1091. doi: 10.1093/pcp/pcm091

Gaedeke, N., Klein, M., Kolukisaoglu, U., Forestier, C., Muller, A., Ansorge, M., et al. (2001). The Arabidopsis thaliana ABC transporter AtMRP5 controls root development and stomata movement. EMBO J. 20, 1875-1887. doi: 10.1093/emboj/20.8.1875

Gaillard, S., Jacquet, H., Vavasseur, A., Leonhardt, N., and Forestier, C. (2008). AtMRP6/AtABCC6, an ATP-binding cassette transporter gene expressed during early steps of seedling development and up-regulated by cadmium in Arabidopsis thaliana. BMC Plant Biol. 8:22. doi: 10.1186/1471-2229-8-22

Gomez, C., Terrier, N., Torregrosa, L., Vialet, S., Fournier-Level, A., Verries, C., et al. (2009). Grapevine MATE-type proteins act as vacuolar $\mathrm{H}^{+}$dependent acylated anthocyanin transporters. Plant Physiol. 150, 402-415. doi: $10.1104 /$ pp.109.135624

Goodman, C. D., Casati, P., and Walbot, V. (2004). A multidrug resistanceassociated protein involved in anthocyanin transport in Zea mays. Plant Cell 16, 1812-1826. doi: 10.1105/tpc.022574

Goswitz, V. C., and Brooker, R. J. (1995). Structural features of the uniporter/symporter/antiporter superfamily. Protein Sci. 4, 534-537. doi: $10.1002 /$ pro. 5560040319

Guo, B., Jin, Y., Wussler, C., Blancaflor, E. B., Motes, C. M., and Versaw, W. K. (2008). Functional analysis of the Arabidopsis PHT4 family of intracellular phosphate transporters. New Phytol. 177, 889-898. doi: 10.1111/j.14698137.2007.02331.x 
Guo, F. Q., Wang, R., Chen, M., and Crawford, N. M. (2001). The Arabidopsis dualaffinity nitrate transporter gene AtNRT1.1 (CHL1) is activated and functions in nascent organ development during vegetative and reproductive growth. Plant Cell 13, 1761-1777. doi: 10.1105/tpc.13.8.1761

Guo, F. Q., Young, J., and Crawford, N. M. (2003). The nitrate transporter AtNRT1.1 (CHL1) functions in stomatal opening and contributes to drought susceptibility in Arabidopsis. Plant Cell 15, 107-117. doi: 10.1105/tpc.006312

Hassler, S., Lemke, L., Jung, B., Mohlmann, T., Kruger, F., Schumacher, K., et al. (2012). Lack of the Golgi phosphate transporter PHT4;6 causes strong developmental defects, constitutively activated disease resistance mechanisms and altered intracellular phosphate compartmentation in Arabidopsis. Plant J. 72, 732-744. doi: 10.1111/j.1365-313X.2012.05106.x

Haydon, M. J., and Cobbett, C. S. (2007). A novel major facilitator superfamily protein at the tonoplast influences zinc tolerance and accumulation in Arabidopsis. Plant Physiol. 143, 1705-1719. doi: 10.1104/pp.106.092015

Haydon, M. J., Kawachi, M., Wirtz, M., Hillmer, S., Hell, R., and Kramer, U. (2012). Vacuolar nicotianamine has critical and distinct roles under iron deficiency and for zinc sequestration in Arabidopsis. Plant Cell 24, 724-737. doi: 10.1105/tpc.111.095042

Higgins, C. F., Hiles, I. D., Salmond, G. P., Gill, D. R., Downie, J. A., Evans, I. J., et al. (1986). A family of related ATP-binding subunits coupled to many distinct biological processes in bacteria. Nature 323, 448-450. doi: 10.1038/323448a0

Ho, C. H., Lin, S. H., Hu, H. C., and Tsay, Y. F. (2009). CHL1 functions as a nitrate sensor in plants. Cell 138, 1184-1194. doi: 10.1016/j.cell.2009.07.004

Huala, E., Dickerman, A. W., Garcia-Hernandez, M., Weems, D., Reiser, L., Lafond, F., et al. (2001). The Arabidopsis Information Resource (TAIR): a comprehensive database and web-based information retrieval, analysis, and visualization system for a model plant. Nucleic Acids Res. 29, 102-105. doi: 10.1093/nar/29.1.102

Irigoyen, S., Karlsson, P. M., Kuruvilla, J., Spetea, C., and Versaw, W. K. (2011) The sink-specific plastidic phosphate transporter PHT4;2 influences starch accumulation and leaf size in Arabidopsis. Plant Physiol. 157, 1765-1777. doi: $10.1104 /$ pp.111.181925

Ito, H., and Gray, W. M. (2006). A gain-of-function mutation in the Arabidopsis pleiotropic drug resistance transporter PDR9 confers resistance to auxinic herbicides. Plant Physiol. 142, 63-74. doi: 10.1104/pp.106.084533

Jasinski, M., Stukkens, Y., Degand, H., Purnelle, B., Marchand-Brynaert, J., and Boutry, M. (2001). A plant plasma membrane ATP binding cassette-type transporter is involved in antifungal terpenoid secretion. Plant Cell 13, 1095-1107. doi: 10.1105/tpc.13.5.1095

Kamimoto, Y., Terasaka, K., Hamamoto, M., Takanashi, K., Fukuda, S., Shitan, N., et al. (2012). Arabidopsis ABCB21 is a facultative auxin importer/exporter regulated by cytoplasmic auxin concentration. Plant Cell Physiol. 53, 2090-2100. doi: $10.1093 / \mathrm{pcp} / \mathrm{pcs} 149$

Kaneda, M., Schuetz, M., Lin, B. S., Chanis, C., Hamberger, B., Western, T. L., et al. (2011). ABC transporters coordinately expressed during lignification of Arabidopsis stems include a set of ABCBs associated with auxin transport. J. Exp. Bot. 62, 2063-2077. doi: 10.1093/jxb/erq416

Kang, J., Hwang, J. U., Lee, M., Kim, Y. Y., Assmann, S. M., Martinoia, E., et al. (2010). PDR-type ABC transporter mediates cellular uptake of the phytohormone abscisic acid. Proc. Natl. Acad. Sci. U.S.A. 107, 2355-2360. doi: 10.1073/pnas.0909222107

Kang, J., Park, J., Choi, H., Burla, B., Kretzschmar, T., Lee, Y., et al. (2011). Plant ABC transporters. Arabidopsis Book 9, e0153. doi: 10.1199/tab.0153

Kim, D. Y., Bovet, L., Maeshima, M., Martinoia, E., and Lee, Y. (2007). The ABC transporter AtPDR8 is a cadmium extrusion pump conferring heavy metal resistance. Plant J. 50, 207-218. doi: 10.1111/j.1365-313X.2007.03044.X

Kim, D. Y., Jin, J. Y., Alejandro, S., Martinoia, E., and Lee, Y. (2010). Overexpression of AtABCG36 improves drought and salt stress resistance in Arabidopsis. Physiol. Plant 139, 170-180. doi: 10.1111/j.1399-3054.2010.01353.x

Klein, M., Geisler, M., Suh, S. J., Kolukisaoglu, H. U., Azevedo, L., Plaza, S., et al. (2004). Disruption of AtMRP4, a guard cell plasma membrane ABCC-type ABC transporter, leads to deregulation of stomatal opening and increased drought susceptibility. Plant J. 39, 219-236. doi: 10.1111/j.1365-313X.2004.02125.x

Klein, M., Perfus-Barbeoch, L., Frelet, A., Gaedeke, N., Reinhardt, D., MuellerRoeber, B., et al. (2003). The plant multidrug resistance ABC transporter AtMRP5 is involved in guard cell hormonal signalling and water use. Plant J. 33, 119-129. doi: 10.1046/j.1365-313X.2003.016012.x

Klepek, Y. S., Geiger, D., Stadler, R., Klebl, F., Landouar-Arsivaud, L., Lemoine, R., et al. (2005). Arabidopsis POLYOL TRANSPORTER5, a new member of the monosaccharide transporter-like superfamily, mediates $\mathrm{H}^{+}$-Symport of numerous substrates, including myo-inositol, glycerol, and ribose. Plant Cell 17, 204-218. doi: 10.1105/tpc.104.026641

Kobae, Y., Sekino, T., Yoshioka, H., Nakagawa, T., Martinoia, E., and Maeshima, M. (2006). Loss of AtPDR8, a plasma membrane ABC transporter of Arabidopsis thaliana, causes hypersensitive cell death upon pathogen infection. Plant Cell Physiol. 47, 309-318. doi: 10.1093/pcp/pcj001

Krattinger, S. G., Lagudah, E. S., Spielmeyer, W., Singh, R. P., Huerta-Espino, J., McFadden, H., et al. (2009). A putative ABC transporter confers durable resistance to multiple fungal pathogens in wheat. Science 323, 1360-1363. doi: 10.1126/science.1166453

Krouk, G., Lacombe, B., Bielach, A., Perrine-Walker, F., Malinska, K., Mounier, E., et al. (2010). Nitrate-regulated auxin transport by NRT1.1 defines a mechanism for nutrient sensing in plants. Dev. Cell 18, 927-937. doi: 10.1016/j.devcel.2010.05.008

Kubes, M., Yang, H., Richter, G. L., Cheng, Y., Mlodzinska, E., Wang, X. et al. (2012). The Arabidopsis concentration-dependent influx/efflux transporter ABCB4 regulates cellular auxin levels in the root epidermis. Plant J. 69, 640-654. doi: 10.1111/j.1365-313X.2011.04818.x

Lee, M., Choi, Y., Burla, B., Kim, Y. Y., Jeon, B., Maeshima, M., et al. (2008). The ABC transporter AtABCB14 is a malate importer and modulates stomatal response to CO2. Nat. Cell Biol. 10, 1217-1223. doi: 10.1038/ncb1782

Lee, M., Lee, K., Lee, J., Noh, E. W., and Lee, Y. (2005). AtPDR12 contributes to lead resistance in Arabidopsis. Plant Physiol. 138, 827-836. doi: 10.1104/pp.104.058107

Lewis, D. R., Miller, N. D., Splitt, B. L., Wu, G., and Spalding, E. P. (2007). Separating the roles of acropetal and basipetal auxin transport on gravitropism with mutations in two Arabidopsis multidrug resistance-like ABC transporter genes. Plant Cell 19, 1838-1850. doi: 10.1105/tpc.107.051599

Li, L., He, Z., Pandey, G. K., Tsuchiya, T., and Luan, S. (2002). Functional cloning and characterization of a plant efflux carrier for multidrug and heavy metal detoxification. J. Biol. Chem. 277, 5360-5368. doi: 10.1074/jbc.M108777200

Li, R., Li, J., Li, S., Qin, G., Novak, O., Pencik, A., et al. (2014). ADP1 affects plant architecture by regulating local auxin biosynthesis. PLoS Genet. 10:e1003954. doi: 10.1371/journal.pgen.1003954

Lin, R., and Wang, H. (2005). Two homologous ATP-binding cassette transporter proteins, AtMDR1 and AtPGP1, regulate Arabidopsis photomorphogenesis and root development by mediating polar auxin transport. Plant Physiol. 138, 949-964. doi: 10.1104/pp.105.061572

Liu, J., Magalhaes, J. V., Shaff, J., and Kochian, L. V. (2009). Aluminum-activated citrate and malate transporters from the MATE and ALMT families function independently to confer Arabidopsis aluminum tolerance. Plant J. 57, 389-399. doi: 10.1111/j.1365-313X.2008.03696.X

Liu, K. H., Huang, C. Y., and Tsay, Y. F. (1999). CHL1 is a dual-affinity nitrate transporter of Arabidopsis involved in multiple phases of nitrate uptake. Plant Cell 11, 865-874. doi: 10.1105/tpc.11.5.865

Lu, Y. P., Li, Z. S., Drozdowicz, Y. M., Hortensteiner, S., Martinoia, E., and Rea, P. A. (1998). AtMRP2, an Arabidopsis ATP binding cassette transporter able to transport glutathione S-conjugates and chlorophyll catabolites: functional comparisons with Atmrp1. Plant Cell 10, 267-282.

Lu, Y. P., Li, Z. S., and Rea, P. A. (1997). AtMRP1 gene of Arabidopsis encodes a glutathione S-conjugate pump: isolation and functional definition of a plant ATPbinding cassette transporter gene. Proc. Natl. Acad. Sci. U.S.A. 94, 8243-8248. doi: $10.1073 /$ pnas.94.15.8243

Magalhaes, J. V. (2010). How a microbial drug transporter became essential for crop cultivation on acid soils: aluminium tolerance conferred by the multidrug and toxic compound extrusion (MATE) family. Ann. Bot. 106, 199-203. doi: $10.1093 / \mathrm{aob} / \mathrm{mcq} 115$

Magalhaes, J. V., Liu, J., Guimaraes, C. T., Lana, U. G., Alves, V. M., Wang, Y. H., et al. (2007). A gene in the multidrug and toxic compound extrusion (MATE) family confers aluminum tolerance in sorghum. Nat. Genet. 39, 1156-1161. doi: $10.1038 / \mathrm{ng} 2074$

Marinova, K., Pourcel, L., Weder, B., Schwarz, M., Barron, D., Routaboul, J. M., et al. (2007). The Arabidopsis MATE transporter TT12 acts as a vacuolar flavonoid $/ \mathrm{H}^{+}$-antiporter active in proanthocyanidin-accumulating cells of the seed coat. Plant Cell 19, 2023-2038. doi: 10.1105/tpc.106.046029

Maron, L. G., Pineros, M. A., Guimaraes, C. T., Magalhaes, J. V., Pleiman, J. K., Mao, C., et al. (2010). Two functionally distinct members of the MATE (multi-drug and toxic compound extrusion) family of transporters potentially 
underlie two major aluminum tolerance QTLs in maize. Plant J. 61, 728-740. doi: 10.1111/j.1365-313X.2009.04103.x

Martinoia, E., Grill, E., Tommasini, R., Kreuz, K., and Amrhein, N. (1993). ATPdependent glutathione S-conjugate export pump in the vacuolar membrane of plants. Nature 364, 247-249. doi: 10.1038/364247a0

Mathews, H., Clendennen, S. K., Caldwell, C. G., Liu, X. L., Connors, K., Matheis, N., et al. (2003). Activation tagging in tomato identifies a transcriptional regulator of anthocyanin biosynthesis, modification, and transport. Plant Cell 15, 1689-1703. doi: 10.1105/tpc.012963

Misson, J., Thibaud, M. C., Bechtold, N., Raghothama, K., and Nussaume, L. (2004). Transcriptional regulation and functional properties of Arabidopsis Pht1;4, a high affinity transporter contributing greatly to phosphate uptake in phosphate deprived plants. Plant Mol. Biol. 55, 727-741. doi: 10.1007/s11103004-1965-5

Morita, M., Shitan, N., Sawada, K., van Montagu, M. C., Inze, D., Rischer, H., et al. (2009). Vacuolar transport of nicotine is mediated by a multidrug and toxic compound extrusion (MATE) transporter in Nicotiana tabacum. Proc. Natl. Acad. Sci. U.S.A. 106, 2447-2452. doi: 10.1073/pnas.0812512106

Mravec, J., Kubes, M., Bielach, A., Gaykova, V., Petrasek, J., Skupa, P., et al. (2008). Interaction of PIN and PGP transport mechanisms in auxin distribution-dependent development. Development 135, 3345-3354. doi: 10.1242/dev.021071

Nagarajan, V. K., Jain, A., Poling, M. D., Lewis, A. J., Raghothama, K. G., and Smith, A. P. (2011). Arabidopsis Pht 1;5 mobilizes phosphate between source and sink organs and influences the interaction between phosphate homeostasis and ethylene signaling. Plant Physiol. 156, 1149-1163. doi: 10.1104/pp.111.174805

Nagy, R., Grob, H., Weder, B., Green, P., Klein, M., Frelet-Barrand, A., et al. (2009). The Arabidopsis ATP-binding cassette protein AtMRP5/AtABCC5 is a high affinity inositol hexakisphosphate transporter involved in guard cell signaling and phytate storage. J. Biol. Chem. 284, 33614-33622. doi: 10.1074/jbc.M109.030247

Nawrath, C., Heck, S., Parinthawong, N., and Metraux, J. P. (2002). EDS5, an essential component of salicylic acid-dependent signaling for disease resistance in Arabidopsis, is a member of the MATE transporter family. Plant Cell 14, 275-286. doi: 10.1105/tpc.010376

Noh, B., Bandyopadhyay, A., Peer, W. A., Spalding, E. P., and Murphy, A. S. (2003). Enhanced gravi- and phototropism in plant mdr mutants mislocalizing the auxin efflux protein PIN1. Nature 423, 999-1002. doi: 10.1038/nature01716

Noh, B., Murphy, A. S., and Spalding, E. P. (2001). Multidrug resistance-like genes of Arabidopsis required for auxin transport and auxin-mediated development. Plant Cell 13, 2441-2454. doi: 10.1105/tpc.13.11.2441

Nussaume, L., Kanno, S., Javot, H., Marin, E., Pochon, N., Ayadi, A., et al. (2011). Phosphate import in plants: focus on the PHT1 transporters. Front Plant Sci. 2:83. doi: $10.3389 /$ fpls.2011.00083

Pao, S. S., Paulsen, I. T., and Saier, M. H. Jr. (1998). Major facilitator superfamily. Microbiol. Mol. Biol. Rev. 62, 1-34.

Park, J., Song, W. Y., Ko, D., Eom, Y., Hansen, T. H., Schiller, M., et al. (2012). The phytochelatin transporters AtABCC1 and AtABCC2 mediate tolerance to cadmium and mercury. Plant J. 69, 278-288. doi: 10.1111/j.1365313X.2011.04789.x

Paulsen, I. T. (2003). Multidrug efflux pumps and resistance: regulation and evolution. Curr. Opin. Microbiol. 6, 446-451. doi: 10.1016/j.mib.2003.08.005

Petrasek, J., Mravec, J., Bouchard, R., Blakeslee, J. J., Abas, M., Seifertova, D., et al. (2006). PIN proteins perform a rate-limiting function in cellular auxin efflux. Science 312, 914-918. doi: 10.1126/science. 1123542

Pineau, C., Loubet, S., Lefoulon, C., Chalies, C., Fizames, C., Lacombe, B., et al. (2012). Natural variation at the FRD3 MATE transporter locus reveals cross-talk between Fe homeostasis and $\mathrm{Zn}$ tolerance in Arabidopsis thaliana. PLoS Genet. 8:e1003120. doi: 10.1371/journal.pgen.1003120

Raichaudhuri, A., Peng, M., Naponelli, V., Chen, S., Sanchez-Fernandez, R., Gu, H., et al. (2009). Plant vacuolar ATP-binding cassette transporters that translocate folates and antifolates in vitro and contribute to antifolate tolerance in vivo. J. Biol. Chem. 284, 8449-8460. doi: 10.1074/jbc.M808632200

Rea, P. A. (2007). Plant ATP-binding cassette transporters. Annu. Rev. Plant Biol. 58, 347-375. doi: 10.1146/annurev.arplant.57.032905.105406

Reinders, A., Panshyshyn, J. A., and Ward, J. M. (2005). Analysis of transport activity of Arabidopsis sugar alcohol permease homolog AtPLT5. J. Biol. Chem. 280, 1594-1602. doi: 10.1074/jbc.M410831200

Remans, T., Nacry, P., Pervent, M., Filleur, S., Diatloff, E., Mounier, E., et al. (2006). The Arabidopsis NRT1.1 transporter participates in the signaling pathway triggering root colonization of nitrate-rich patches. Proc. Natl. Acad. Sci. U.S.A. 103, 19206-19211. doi: 10.1073/pnas.0605275103

Remy, E., Baster, P., Friml, J., and Duque, P. (2013a). ZIFL1.1 transporter modulates polar auxin transport by stabilizing membrane abundance of multiple PINs in Arabidopsis root tip. Plant Signal Behav. 8. doi: 10.4161/psb.25688. Available online at: https://www.landesbioscience.com/journals/psb/article/25688/

Remy, E., Cabrito, T. R., Baster, P., Batista, R. A., Teixeira, M. C., Friml, J., et al. (2013b). A major facilitator superfamily transporter plays a dual role in polar auxin transport and drought stress tolerance in Arabidopsis. Plant Cell 25, 901-926. doi: 10.1105/tpc.113.110353

Remy, E., Cabrito, T. R., Batista, R. A., Hussein, M. A. M., Teixeira, M. C., Athanasiadis, A., et al. (2014). Intron retention in the 5'UTR of the novel ZIF2 transporter enhances translation to promote zinc tolerance in Arabidopsis. PLoS Genet. 10:e1004375. doi: 10.1371/journal.pgen.1004375

Remy, E., Cabrito, T. R., Batista, R. A., Teixeira, M. C., Sa-Correia, I., and Duque, P. (2012). The Pht1;9 and Pht 1;8 transporters mediate inorganic phosphate acquisition by the Arabidopsis thaliana root during phosphorus starvation. New Phytol. 195, 356-371. doi: 10.1111/j.1469-8137.2012.04167.x

Ren, Q., Kang, K. H., and Paulsen, I. T. (2004). TransportDB: a relational database of cellular membrane transport systems. Nucleic Acids Res. 32, D284-D288. doi: 10.1093/nar/gkh016

Risk, J. M., Selter, L. L., Chauhan, H., Krattinger, S. G., Kumlehn, J., Hensel, G., et al. (2013). The wheat Lr34 gene provides resistance against multiple fungal pathogens in barley. Plant Biotechnol. J. 11, 847-854. doi: 10.1111/pbi.12077

Ruzicka, K., Strader, L. C., Bailly, A., Yang, H., Blakeslee, J., Langowski, L., et al. (2010). Arabidopsis PIS1 encodes the ABCG37 transporter of auxinic compounds including the auxin precursor indole-3-butyric acid. Proc. Natl. Acad. Sci. U.S.A. 107, 10749-10753. doi: 10.1073/pnas. 1005878107

Ryan, P. R., Raman, H., Gupta, S., Horst, W. J., and Delhaize, E. (2009). A second mechanism for aluminum resistance in wheat relies on the constitutive efflux of citrate from roots. Plant Physiol. 149, 340-351. doi: 10.1104/pp.108. 129155

Sanchez-Fernandez, R., Davies, T. G., Coleman, J. O., and Rea, P. A. (2001). The Arabidopsis thaliana $\mathrm{ABC}$ protein superfamily, a complete inventory. J. Biol. Chem. 276, 30231-30244. doi: 10.1074/jbc.M103104200

Santelia, D., Vincenzetti, V., Azzarello, E., Bovet, L., Fukao, Y., Duchtig, P., et al. (2005). MDR-like ABC transporter AtPGP4 is involved in auxin-mediated lateral root and root hair development. FEBS Lett. 579, 5399-5406. doi: 10.1016/j.febslet.2005.08.061

Sauer, N., Friedlander, K., and Graml-Wicke, U. (1990). Primary structure, genomic organization and heterologous expression of a glucose transporter from Arabidopsis thaliana. EMBO J. 9, 3045-3050.

Sawaki, Y., Kihara-Doi, T., Kobayashi, Y., Nishikubo, N., Kawazu, T., Koyama, H., et al. (2013). Characterization of Al-responsive citrate excretion and citratetransporting MATEs in Eucalyptus camaldulensis. Planta 237, 979-989. doi: $10.1007 / \mathrm{s} 00425-012-1810-\mathrm{z}$

Serrano, M., Wang, B., Aryal, B., Garcion, C., Abou-Mansour, E., Heck, S., et al. (2013). Export of salicylic acid from the chloroplast requires the multidrug and toxin extrusion-like transporter EDS5. Plant Physiol. 162, 1815-1821. doi: 10.1104/pp.113.218156

Sherson, S. M., Hemmann, G., Wallace, G., Forbes, S., Germain, V., Stadler, R., et al. (2000). Monosaccharide/proton symporter AtSTP1 plays a major role in uptake and response of Arabidopsis seeds and seedlings to sugars. Plant J. 24, 849-857. doi: 10.1046/j.1365-313x.2000.00935.x

Shi, J., Wang, H., Schellin, K., Li, B., Faller, M., Stoop, J. M., et al. (2007). Embryospecific silencing of a transporter reduces phytic acid content of maize and soybean seeds. Nat. Biotechnol. 25, 930-937. doi: 10.1038/nbt1322

Shin, H., Shin, H. S., Dewbre, G. R., and Harrison, M. J. (2004). Phosphate transport in Arabidopsis: Pht1;1 and Pht1;4 play a major role in phosphate acquisition from both low- and high-phosphate environments. Plant J. 39, 629-642. doi: 10.1111/j.1365-313X.2004.02161.X

Shoji, T., Inai, K., Yazaki, Y., Sato, Y., Takase, H., Shitan, N., et al. (2009). Multidrug and toxic compound extrusion-type transporters implicated in vacuolar sequestration of nicotine in tobacco roots. Plant Physiol. 149, 708-718. doi: $10.1104 /$ pp.108.132811

Song, W. Y., Park, J., Mendoza-Cozatl, D. G., Suter-Grotemeyer, M., Shim, D., Hortensteiner, S., et al. (2010). Arsenic tolerance in Arabidopsis is mediated by two ABCC-type phytochelatin transporters. Proc. Natl. Acad. Sci. U.S.A. 107, 21187-21192. doi: 10.1073/pnas.1013964107 
Stadler, R., Buttner, M., Ache, P., Hedrich, R., Ivashikina, N., Melzer, M., et al. (2003). Diurnal and light-regulated expression of AtSTP1 in guard cells of Arabidopsis. Plant Physiol. 133, 528-537. doi: 10.1104/pp.103.024240

Stein, M., Dittgen, J., Sanchez-Rodriguez, C., Hou, B. H., Molina, A., SchulzeLefert, P., et al. (2006). Arabidopsis PEN3/PDR8, an ATP binding cassette transporter, contributes to nonhost resistance to inappropriate pathogens that enter by direct penetration. Plant Cell 18, 731-746. doi: 10.1105/tpc.105.038372

Strader, L. C., and Bartel, B. (2009). The Arabidopsis PLEIOTROPIC DRUG RESISTANCE8/ABCG36 ATP binding cassette transporter modulates sensitivity to the auxin precursor indole-3-butyric acid. Plant Cell 21, 1992-2007. doi: $10.1105 /$ tpc. 109.065821

Stukkens, Y., Bultreys, A., Grec, S., Trombik, T., Vanham, D., and Boutry, M. (2005). NpPDR1, a pleiotropic drug resistance-type ATP-binding cassette transporter from Nicotiana plumbaginifolia, plays a major role in plant pathogen defense. Plant Physiol. 139, 341-352. doi: 10.1104/pp.105.062372

Suh, S. J., Wang, Y. F., Frelet, A., Leonhardt, N., Klein, M., Forestier, C., et al. (2007), The ATP binding cassette transporter AtMRP5 modulates anion and calcium channel activities in Arabidopsis guard cells. J. Biol. Chem. 282, 1916-1924. doi: 10.1074/jbc.M607926200

Sun, X., Gilroy, E. M., Chini, A., Nurmberg, P. L., Hein, I., Lacomme, C., et al. (2011). ADS1 encodes a MATE-transporter that negatively regulates plant disease resistance. New Phytol. 192, 471-482. doi: 10.1111/j.14698137.2011.03820.x

Takanashi, K., Yokosho, K., Saeki, K., Sugiyama, A., Sato, S., Tabata, S., et al. (2013). LjMATE1: a citrate transporter responsible for iron supply to the nodule infection zone of Lotus japonicus. Plant Cell Physiol. 54, 585-594. doi: $10.1093 / \mathrm{pcp} / \mathrm{pct} 019$

Terasaka, K., Blakeslee, J. J., Titapiwatanakun, B., Peer, W. A., Bandyopadhyay, A., Makam, S. N., et al. (2005). PGP4, an ATP binding cassette P-glycoprotein, catalyzes auxin transport in Arabidopsis thaliana roots. Plant Cell 17, 2922-2939. doi: $10.1105 /$ tpc. 105.035816

Thomas, C., Rajagopal, A., Windsor, B., Dudler, R., Lloyd, A., and Roux, S. J. (2000). A role for ectophosphatase in xenobiotic resistance. Plant Cell 12, 519-533. doi: 10.1105/tpc.12.4.519

Thompson, E. P., Wilkins, C., Demidchik, V., Davies, J. M., and Glover, B. J. (2010). An Arabidopsis flavonoid transporter is required for anther dehiscence and pollen development. J. Exp. Bot. 61, 439-451. doi: 10.1093/jxb/erp312

Titapiwatanakun, B., Blakeslee, J. J., Bandyopadhyay, A., Yang, H., Mravec, J., Sauer, M., et al. (2009). ABCB19/PGP19 stabilises PIN1 in membrane microdomains in Arabidopsis. Plant J. 57, 27-44. doi: 10.1111/j.1365-313X.2008.03668.x

Tiwari, M., Sharma, D., Singh, M., Tripathi, R. D., and Trivedi, P. K. (2014). Expression of OsMATE1 and OsMATE2 alters development, stress responses and pathogen susceptibility in Arabidopsis. Sci. Rep. 4, 3964. doi: $10.1038 /$ srep03964

Tommasini, R., Vogt, E., Fromenteau, M., Hortensteiner, S., Matile, P., Amrhein, N., et al. (1998). An ABC-transporter of Arabidopsis thaliana has both glutathioneconjugate and chlorophyll catabolite transport activity. Plant J. 13, 773-780. doi: 10.1046/j.1365-313X.1998.00076.x

Tsay, Y. F., Chiu, C. C., Tsai, C. B., Ho, C. H., and Hsu, P. K. (2007). Nitrate transporters and peptide transporters. FEBS Lett. 581, 2290-2300. doi: 10.1016/j.febslet.2007.04.047

Underwood, W., and Somerville, S. C. (2013). Perception of conserved pathogen elicitors at the plasma membrane leads to relocalization of the Arabidopsis PEN3 transporter. Proc. Natl. Acad. Sci. U.S.A. 110, 12492-12497. doi: 10.1073/pnas.1218701110

van den Brule, S., Muller, A., Fleming, A. J., and Smart, C. C. (2002). The ABC transporter SpTUR2 confers resistance to the antifungal diterpene sclareol. Plant J. 30, 649-662. doi: 10.1046/j.1365-313X.2002.01321.x

Walch-Liu, P., and Forde, B. G. (2008). Nitrate signalling mediated by the NRT1.1 nitrate transporter antagonises L-glutamate-induced changes in root architecture. Plant J. 54, 820-828. doi: 10.1111/j.1365-313X.2008.03443.x

Wang, G. Y., Shi, J. L., Ng, G., Battle, S. L., Zhang, C., and Lu, H. (2011). Circadian clock-regulated phosphate transporter PHT4;1 plays an important role in Arabidopsis defense. Mol. Plant 4, 516-526. doi: 10.1093/mp/ssr016
Windsor, B., Roux, S. J., and Lloyd, A. (2003). Multiherbicide tolerance conferred by AtPgp1 and apyrase overexpression in Arabidopsis thaliana. Nat. Biotechnol. 21, 428-433. doi: 10.1038/nbt809

Wisniewska, J., Xu, J., Seifertova, D., Brewer, P. B., Ruzicka, K., Blilou, I., et al. (2006). Polar PIN localization directs auxin flow in plants. Science 312, 883. doi: $10.1126 /$ science. 1121356

Wu, G., Lewis, D. R., and Spalding, E. P. (2007). Mutations in Arabidopsis multidrug resistance-like $\mathrm{ABC}$ transporters separate the roles of acropetal and basipetal auxin transport in lateral root development. Plant Cell 19, 1826-1837. doi: $10.1105 /$ tpc. 106.048777

Xin, X. F., Nomura, K., Underwood, W., and He, S. Y. (2013). Induction and suppression of PEN3 focal accumulation during Pseudomonas syringae pv. tomato DC3000 infection of Arabidopsis. Mol. Plant Microbe. Interact. 26, 861-867. doi: 10.1094/MPMI-11-12-0262-R

Yamasaki, K., Motomura, Y., Yagi, Y., Nomura, H., Kikuchi, S., Nakai, M., et al. (2013). Chloroplast envelope localization of EDS5, an essential factor for salicylic acid biosynthesis in Arabidopsis thaliana. Plant Signal. Behav. 8, e23603. doi: $10.4161 /$ psb. 23603

Yang, H., and Murphy, A. S. (2009). Functional expression and characterization of Arabidopsis ABCB, AUX 1 and PIN auxin transporters in Schizosaccharomyces pombe. Plant J. 59, 179-191. doi: 10.1111/j.1365-313X.2009.03856.x

Yang, X. Y., Yang, J. L., Zhou, Y., Pineros, M. A., Kochian, L. V., Li, G. X., et al. (2011). A de novo synthesis citrate transporter, Vigna umbellata multidrug and toxic compound extrusion, implicates in Al-activated citrate efflux in rice bean (Vigna umbellata) root apex. Plant Cell Environ. 34, 2138-2148. doi: 10.1111/j.1365-3040.2011.02410.x

Yokosho, K., Yamaji, N., and Ma, J. F. (2010). Isolation and characterisation of two MATE genes in rye. Funct. Plant Biol. 37, 296-303. doi: 10.1071/ FP09265

Yokosho, K., Yamaji, N., and Ma, J. F. (2011). An Al-inducible MATE gene is involved in external detoxification of $\mathrm{Al}$ in rice. Plant J. 68, 1061-1069. doi: 10.1111/j.1365-313X.2011.04757.x

Yokosho, K., Yamaji, N., Ueno, D., Mitani, N., and Ma, J. F. (2009). OsFRDL1 is a citrate transporter required for efficient translocation of iron in rice. Plant Physiol. 149, 297-305. doi: 10.1104/pp.108.128132

Zhao, J., and Dixon, R. A. (2009). MATE transporters facilitate vacuolar uptake of epicatechin 3'-O-glucoside for proanthocyanidin biosynthesis in Medicago truncatula and Arabidopsis. Plant Cell 21, 2323-2340. doi: $10.1105 /$ tpc. 109.067819

Zhao, J., Huhman, D., Shadle, G., He, X. Z., Sumner, L. W., Tang, Y., et al. (2011). MATE2 mediates vacuolar sequestration of flavonoid glycosides and glycoside malonates in Medicago truncatula. Plant Cell 23, 1536-1555. doi: $10.1105 /$ tpc. 110.080804

Zhou, G., Delhaize, E., Zhou, M., and Ryan, P. R. (2013). The barley MATE gene, HvAACT1, increases citrate efflux and $\mathrm{Al}(3+)$ tolerance when expressed in wheat and barley. Ann. Bot. 112, 603-612. doi: 10.1093/aob/ mct135

Conflict of Interest Statement: The authors declare that the research was conducted in the absence of any commercial or financial relationships that could be construed as a potential conflict of interest.

Received: 03 April 2014; accepted: 09 May 2014; published online: 30 May 2014. Citation: Remy E and Duque P (2014) Beyond cellular detoxification: a plethora of physiological roles for MDR transporter homologs in plants. Front. Physiol. 5:201. doi: 10.3389/fphys.2014.00201

This article was submitted to Membrane Physiology and Membrane Biophysics, a section of the journal Frontiers in Physiology.

Copyright $\odot 2014$ Remy and Duque. This is an open-access article distributed under the terms of the Creative Commons Attribution License (CC BY). The use, distribution or reproduction in other forums is permitted, provided the original author(s) or licensor are credited and that the original publication in this journal is cited, in accordance with accepted academic practice. No use, distribution or reproduction is permitted which does not comply with these terms. 